\title{
A NEW POST OCCUPANCY EVALUATION TOOL FOR ASSESSING THE INDOOR ENVIRONMENT QUALITY OF LEARNING ENVIRONMENTS
}

\section{INTRODUCTION}

The EduTool:IEQ is an evaluation tool that provides succinct and targeted information about the indoor environment quality (IEQ) of learning environments. It is suitable for the multidisciplinary groups involved in commissioning, designing, constructing, operating, maintaining and occupying school facilities. IEQ is an environmental issue concerned with the levels of lighting, thermal comfort, air quality and acoustics inside a space. In a school context, IEQ performance is important, as poor IEQ can trigger health and learning difficulties for students and adversely impact on the wellbeing of educators and their students.

The EduTool:IEQ assesses and quantifies the performance of 16 IEQ components identified in the literature as having the greatest potential to impact on effective teaching and learning. The assessment involves collecting objective data about each, using environmental monitoring equipment. The findings of the evaluation are communicated using the EduTool:IEQ info-graphic, which is a data visualisation method. The EduTool:IEQ info-graphic is unique because it enables its users to immediately identify how the 16 IEQ components perform relative to recommended levels of industry practice. Giving stakeholder groups access to this type of information can enable targeted and cost-effective remedial works that benefit students and educators to be identified and undertaken inside the learning environments. The findings also provide a valuable source of feedback loops for built environment professionals seeking information about opportunities to improve their future practice.

\section{CONTEXT - THE IMPACT OF IEQ ON STUDENT WELLBEING}

This chapter outlines the development of a new post occupancy evaluation (POE) tool used to assess the indoor environment quality (IEQ) inside learning environments. POE "is the process of evaluating buildings in a systematic and rigorous manner after they have been built and occupied for some time" (Preiser, 2001, p. 9). POE tools are used by evaluators to control and document the inputs and parameters that are assessed as part of the evaluation process (Baker, 2011). 
Learning environments are complex learning spaces overlaid with environmental, pedagogical, socio-cultural, curricular, motivational, and socio-economic issues (Figure 1) (Higgins, Hall, Wall, Woolner \& McCaughey, 2005). IEQ is an environmental issue concerned with the levels of lighting, thermal comfort, air quality and acoustics inside a space. Poor IEQ performance inside a learning environment can trigger health and learning difficulties for students (Daisy, Angell \& Apte, 2003; Earthman, 2004; Coalition for Healthier Schools, 2013). Young students attending primary and middle schools are particularly vulnerable because of the dynamic state of growth their bodies and minds are undergoing (World Health Organisation, 2006). The risk of environmental exposure is exacerbated inside learning environments because of the amount of time that students spend at school. It is estimated that a student will spend 15,000 compulsory hours in the physical school environment during their formative years and $85 \%$ to $90 \%$ of this time indoors (Johnson \& Kristonis, 2010; Rutter, 1979; USEPA, 2008).

The IEQ performance inside a building may be impacted by how the building has been designed, constructed, maintained and/or operated by the occupants (Vittori, 2002). In this chapter a building with good IEQ performance is defined as one that:

does not cause or aggravate illnesses in the building occupants, assures a high level of comfort to the building's occupants in the performance of the designated activities for which the building has been intended and designed. (Bluyssen \& Loomans, 2003, p. 21)

Appropriately designed school facilities form an important part of promoting effective teaching and learning. A fundamental requirement in the design of educational facilities is to provide an environment that facilitates educational effectiveness and student development without adverse health effects (Ali, Almomani \& Hindeih, 2009). The OECD (2013) defines educational effectiveness as "the ability of a school or school system to adequately accomplish its stated educational objectives" (p. 4). Student development is defined as "the way that a student grows, progresses or increases his or her developmental capabilities" (Rodgers, 1990, p. 4). Adverse health effects are defined as "the causation, promotion, facilitation and/or exacerbation of a structural and/or functional abnormality" (Sherwin, 1983, p. 177).

Educational success can be directly impacted upon by student absenteeism from school and impaired performance whilst at school. In Equity and Quality in Education the OECD (2012) highlights that educational failure can impose a high cost on both the individual and society. The OECD describes the likelihood of fewer life prospects for students who miss out on developing the knowledge and skills that come with gaining a formal education.

In developed countries, asthma is the leading cause of school absenteeism. Research has identified the condition of the learning environment to be a probable asthma trigger (AIHW, 2011; Belanger, Kielb \& Lin, 2006; Simons, Hwang, Fitzgerald, Kielb \& Lin, 2010). In the US there are over seven million students with asthma (CDC, 2012). In Australia it is estimated that one in nine school-aged 


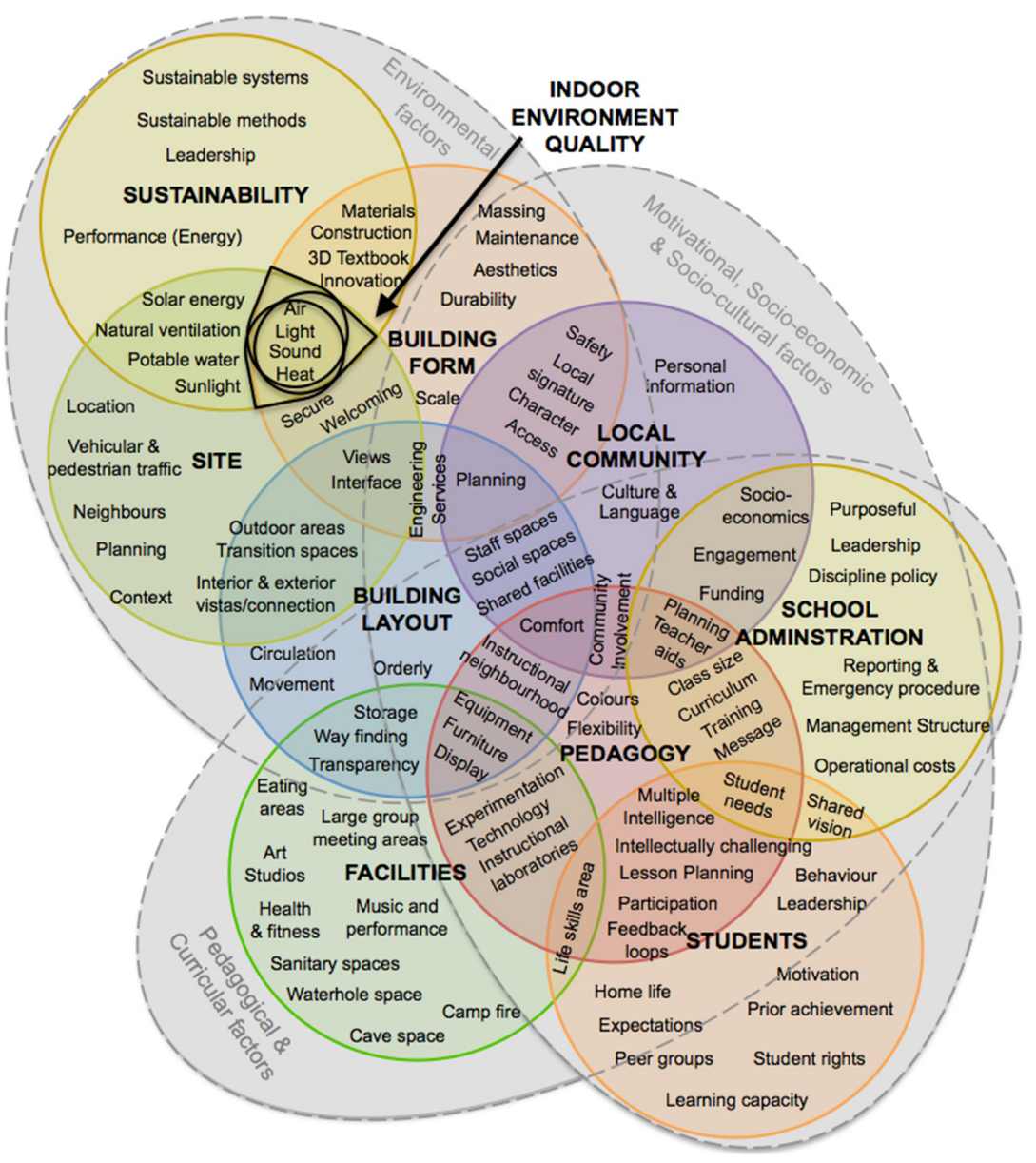

Figure 1. Indoor environment quality positioned amongst the environmental, motivational, socio-economic, socio-cultural, pedagogical and curricular factors that can impact on effective teaching and learning

children has asthma (AFA, 2009; AIHW, 2011). A student with asthma may be absent from school during the period directly after an attack. They may also be absent on days when there are an increased number of triggers present (CDC, 2012). The number of days that a student is absent from school due to asthma can be reduced through appropriate asthma management programs (Grant \& Brito, 2010; Meng, Babey \& Wolstein, 2012). Through assessing the air quality inside the learning environment, the evaluation tool can be used to determine the probable causes of asthma triggers and aid in the development of appropriate asthma management programs, to mitigate the risks. 


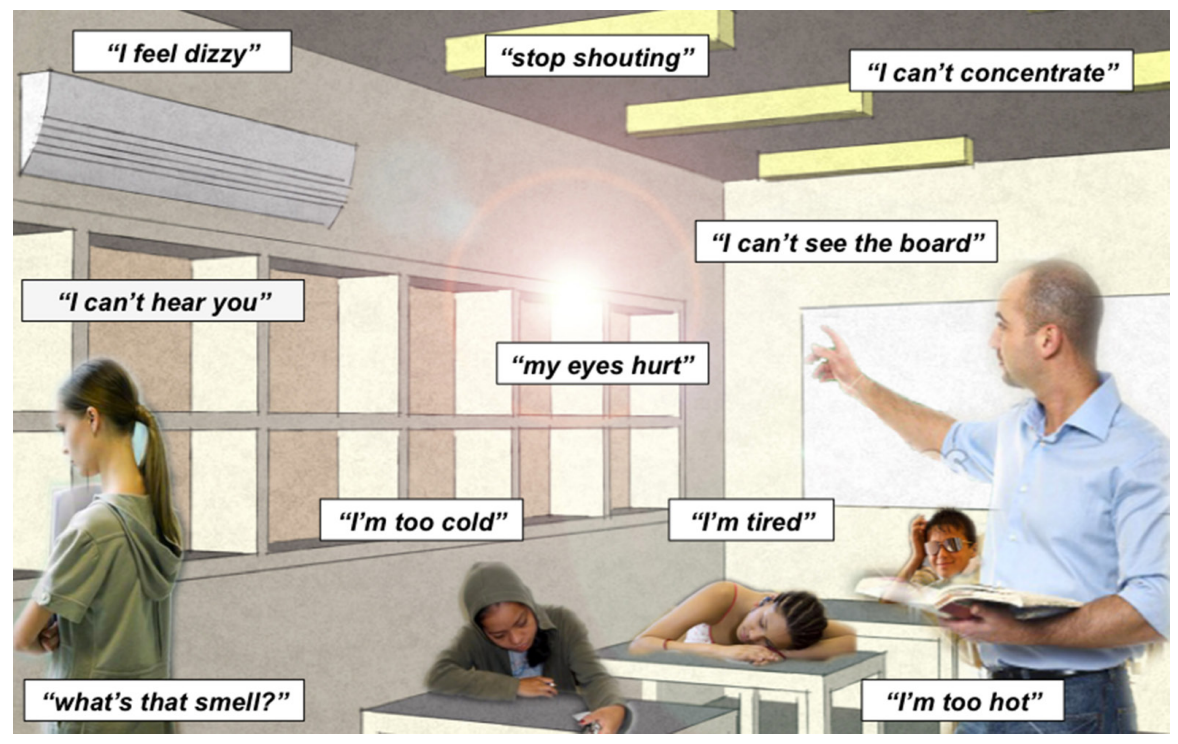

Figure 2. The effects of poor IEQ inside the learning environment on student well-being

Impaired performance relates to students' inability to concentrate, process and retain information about the activities that they are working on in their learning environment (Figure 2). In the United States, Kats (2006) identified "some 55 million students spend[ing] their days in schools that are too often unhealthy and that restrict their ability to learn" (p. 2). In Towards Healthy Schools 2015 (Coalition for Healthier Schools, 2013) the authors argue that the "physical environmental stressors in schools measurably and significantly affect children's achievement" (p. 6).

\section{OBJECTIVE - A NEW IEQ EVALUATION TOOL TO SUPPORT THE EVIDENCE BASED DESIGN OF SCHOOLS}

The purpose behind creating the new POE tool was to provide a multidisciplinary audience comprising stakeholders involved in commissioning, designing, constructing, operating, maintaining and occupying school facilities, with succinct and targeted information about the IEQ performance inside school learning environments. In developing the new POE tool, the writer aimed to fulfil the design criteria set out by a review of existing POE tools. The review included 24 POE tools used for assessing educational facilities and 19 POE tools used for assessing IEQ performance inside buildings.

The identified criteria required a new POE tool for assessing IEQ performance of learning environments to: 
1. Build on the measurement parameters used by the Mobile Architecture and Built Environment Laboratory (MABEL) developed at Deakin University (Luther \& Schwede, 2006). The MABEL system was originally developed to "provide internal environment performance for commercial, industrial and residential buildings" - not educational facilities (Luther \& Schewede, 2006). After trialling MABEL inside a school, Luther (2012) observed that, "in hindsight and in reference to the recent literature and experience from our case studies, the measurement sub-systems [of MABEL] could be dramatically improved" (p. 2). Luther highlighted the importance of evaluating the IEQ performance of educational facilities by collecting data about the IEQ components that were influential on effective teaching and learning.

2. Collect data about the conditions external to the learning environment. Luther (2012) observed that MABEL did not do this, and it was "quite obvious that external weather and solar conditions were the drivers of indoor comfort and energy consumption" (p. 4). He also cited the impact that operable windows could have specifically on air quality and acoustics.

3. Consider how the results would be presented to a wide group of stakeholders. Luther (2012) observed that MABEL "lack[ed] effective presentation and analysis of the results" (p. 7). He argued that addressing this would be "a significant and onerous task, yet, one which is required if scientific results are to influence decision-makers on school budgets" (p. 7).

4. Develop and apply to performance an overall IEQ Index to quantify results, one that allows for the performance of multiple IEQ components to be assessed together. Luther (2012) commented that he was "suspicious of studies where an assessment of a singular sub-system is observed in regards to improved performance or absenteeism" (p. 6).

5. Investigate the relationship between design decisions and outcomes. The need for this was highlighted by Candido, de Dear, Thomas, Kim \& Parkinson (2013, p. 1). They cited research by Newsham et al., and Cooper who attributed the cause of the disconnect to "experimental green technologies that were not well understood and did not perform as expected by the designers who specified them" (p. 42) and a knowledge transfer barrier between the design team and the end-users.

6. Collect objective data about actual building performance. The need for this was highlighted in the Business Case for Green Star Performance (GBCA, 2013). This document forecast that the Green Star Performance tool could have the same impact in Australia as the LEED EBOM tool had in the US. For example, the "LEED EBOM tool drove more certifications in one year than all the other LEED tools have done in their history" (GBCA, 2013, p. 5).

7. Focus on holistic and whole-building approaches to design. This point was raised in a critique by the Environment and Human Health Inc. (EEHI) of the LEED rating tool. EHHI (2010) found that the "scoring system is weighted too heavily towards energy conservation and the use of new and renewable technologies" (p. 7). Citing the EHHI report, the Institute of Medicine (IOM) 
(2011) expressed concern that the bias of green building rating tools may result in 'sustainable buildings' that were neither healthy, nor productive workplaces. The criticism of green building rating tools such as LEED, BREEAM and Green Star was directed at how points are awarded.

8. Have a clearly defined design intention (Adeyeye, Piroozfar, Rosenkind, Winstanley \& Pegg, 2013).

9. Be transparent about its processes (Adeyeye et al., 2013).

10. Be developed to "ensure that the knowledge gained from the research studies is not only disseminated in the academic community but also successfully transferred to the world of designers, builders and financiers of real estate" (Vischer, 2002, p. 29).

\section{METHODOLOGY \& METHODS - ROLE OF THE RESEARCHER AND CONSTRAINTS}

The new evaluation tool was developed as one of the outcomes of the writer's $\mathrm{PhD}$ in Architecture at the University of Melbourne (Soccio, 2014). It aimed to answer the research question: How can indoor environment quality data be collected and analysed to communicate to a multidisciplinary audience, succinct and targeted information about the quality of the environment inside primary and middle school classrooms? The study's aim was to find a way of aiding built environment professionals to apply a whole-building approach to designing IEQ inside the learning environment. The assertion that built environment professionals need to 'broaden' their understanding of IEQ came from opinions expressed in the literature, specifically about the need to improve how IEQ education is taught in tertiary institutions. For example:

- The American Society of Heating, Refrigerating and Air-Conditioning Engineers (ASHRAE, 2010) in its Research Strategic Plan 2010-2015 set the goal to "significantly increase the understanding of energy efficiency, environmental quality and the design of buildings in engineering and architectural education" (p. 21),

- The School of Architecture at the Carnegie Mellon University (Pennsylvania, USA). Loftness, Lam and Hartkopf (2005) argued for the need for "curricular change in architecture and engineering departments to embrace more fully systems integration for building performance" (p. 196); and

- The Faculty of Architecture at Delft University of Technology (Netherlands). Here Bluyssen (2013) proposed a new program to the faculty that would have issues of IEQ and design, more holistically integrated into the curriculum.

The development of the new POE tool was approached by using a critical pragmatist epistemology and in-depth ontology (Froeyman, 2012). This led to the pursuit of pragmatic methods, but also critical thinking about the relationship between the method and the outcome (White, 2004; Joas, 1996). Depth ontology 
was used to seek out the hidden conditions that influence the learning environment operators' day-to-day experience of IEQ (Greener, 2011; Merker, 2010). This informed a decision to approach the research as a rationalist and not as an empiricist.

Rationalists believe that knowledge is gained independently of sense experience, while Empiricists believe that sense experience is the ultimate source knowledge (Plotkin, 2008). Students and educators experience IEQ inside the learning environment as empiricists. Their perception of 'quality' can be biased by the human sensory system (Kim, Paulos \& Mankoff, 2013). Human sensors have limited capacity to experience and differentiate between IEQ components and their varying levels of performance (IPMVP, 2002). Consequently, a subjective evaluation may only capture the occupants" understanding of "what is observable" (Castree, 2005, p. 214) or of concern to them at a specific point in time (IPMVP, 2002). This finding is consistent with that of Kim and de Dear (2012) in a study of how occupant perception of specific IEQ factors affected overall satisfaction. They found that inside office environments, when IEQ factors are performing well "they tend to go unnoticed" (p. 6). However, when the performance of the IEQ factors was perceived to be inadequate and failed to meet occupant expectations it prompted significant overall dissatisfaction.

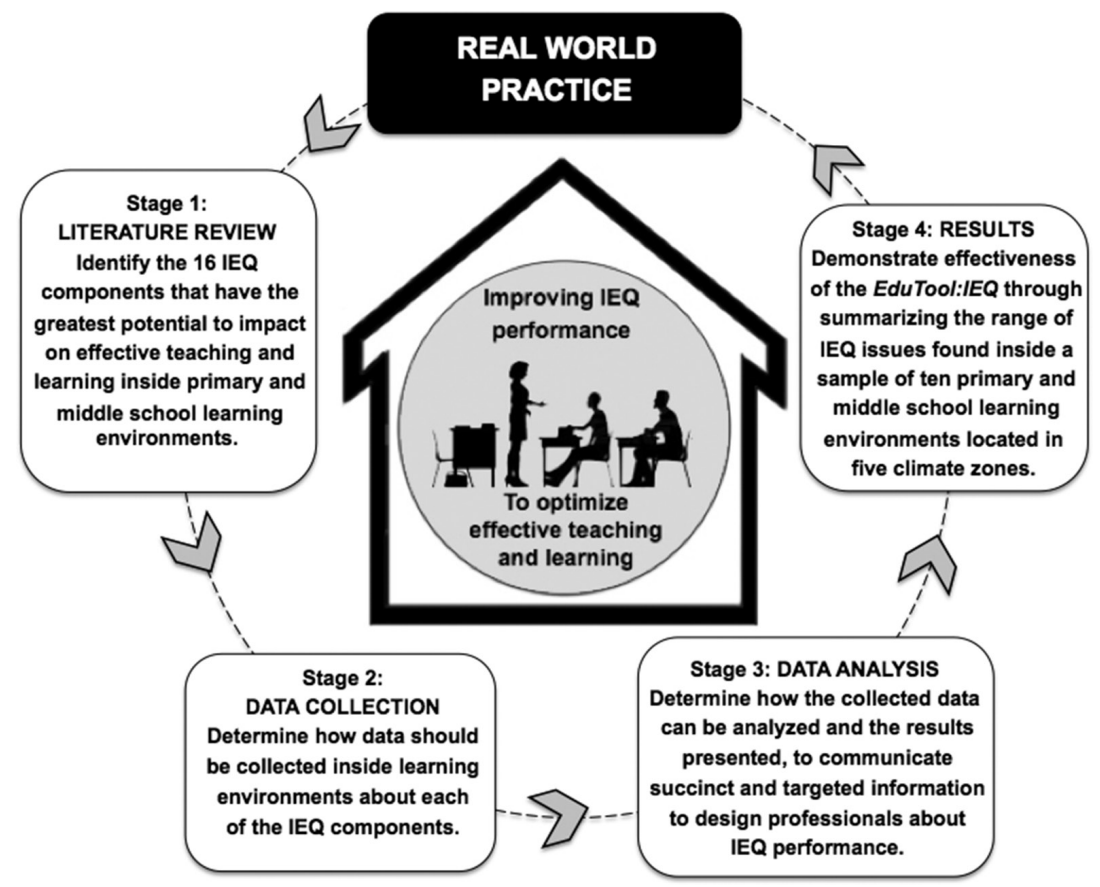

Figure 3. Design of the writer's study outlining the four research stages that centred around the aim to improve IEQ performance inside primary and middle school learning environments to optimise effective teaching and learning 
The new POE tool was developed using an explanatory sequential design framework. This is an approach that starts with a research method or question and uses the findings to inform the subsequent stages of the research (Creswell \& Plano Clark, 2011). The methodology had four distinct stages (Figure 3). Each stage was informed by a subsidiary research question and had practical outcomes that were centred on real world practice and the need to improve the IEQ performance inside primary and middle school learning environments to optimise the opportunities for effective teaching and learning. To aid in the development of the subsidiary research questions, the researcher consulted the Higher Education Design Quality Forum's (HEFCE, 2006) Guide to Post Occupancy Evacuation. The subsidiary questions asked in the study were:

- What are the IEQ components found inside primary and middle school learning environments that have the greatest potential to impact on effective teaching and learning?

- How is data about IEQ collected inside primary and middle school learning environments?

- How can IEQ data be analysed and the results communicated to enable a multidisciplinary audience to describe the overall IEQ performance inside primary and middle school learning environments as well as identify for stakeholders the probable cause of specific IEQ issues?

- What is the IEQ performance inside a sample of existing primary and middle school learning environments, located across five Australian climate zones?

\section{RESULTS - LINKING IEQ TO HEALTH AND WELLBEING}

The new POE tool used for assessing the IEQ performance inside primary to secondary school learning environments is called the EduTool:IEQ. It assesses the performance of the 16 IEQ components that were identified in a literature review as having the greatest potential to impact on effective teaching and learning.

There are four stages involved in using the EduTool:IEQ. The first stage is data collection. The tool prescribes the methods that an assessor should use to collect objective, descriptive and subjective data about the 16 IEQ. Objective data is collected using environmental monitoring equipment. Descriptive data is collected using overt observation about the physical conditions inside the learning environment along with observations about how the occupants' behaviour may have influenced the objective data collected. Subjective data is collected through stakeholder engagement such as focus group activities and questionnaires.

The initial literature review identified the presence of over 40 IEQ components that could impact on the quality of the indoor environment of a learning environment. Using causality theory (and causal chaining) this group of components was reduced to 16 , with groupings of four components chosen for acoustics, lighting, air quality and thermal comfort (Mendell \& Heath, 2005; Soccio, 2014). There is no hierarchy 
amongst these components. This decision was influenced by arguments made in the literature about the need for built environment professionals to conduct their practice with a whole building approach that "takes full advantage of the symbiotic nature of design so that the design elements work to reinforce each other and thereby maximise the ability of the overall building design to fulfil its design objectives effectively and with greater efficiency and also lower capital and operating costs" (ASHRAE, 2009. p. 162).

In the second stage, the data collected about the 16 IEQ components is processed. However, only the objective data is used. Processing the data involves calculating a single quantitative result $(\mathrm{QR})$ for each of the 16 components. In order to do this, it is first necessary to define the 'period of occupancy' under investigation. The QR is a calculation that takes the average of all the data points collected for the component during the period of occupancy. Inside the ten learning environments evaluated in this study using the EduTool:IEQ the period of occupancy was: 'school hours' (7:30am to 4:29pm) on weekdays during term time. The period of occupancy allowed for activities conducted inside the learning environment during, before and after the formal school day. For each component, two QRs were calculated. One was indicative of performance in winter and the other was indicative of the performance in summer. Having two QRs allowed for comparisons to be made.

In the third stage, the QRs calculated for each component were analysed to determine (in qualitative terms) their level of performance. To do this the assessor used the EduTool:IEQ Evaluation Indices - a type of environmental index that quantifies and numerically benchmarks the QR against different levels of industry

Table 1. Example of the EduTool:IEQ Evaluation Indice for carbon dioxide

\begin{tabular}{|c|c|c|c|}
\hline Score & Performance thresholds & Score & Carbon dioxide levels (ppm) \\
\hline 10 & Achieves next practice & 10 & $400 *-600$ \\
\hline 9 & Achieves best practice & 9 & $601-700$ \\
\hline 8 & Achieves excellent practice & 8 & $701-800$ \\
\hline 7 & Achieves good practice & 7 & $801-900$ \\
\hline 6 & Achieves acceptable practice & 6 & $901-1000$ \\
\hline 5 & Achieves minimum practice & 5 & $1001-1100$ \\
\hline 4 & Below minimum practice & 4 & $1101-1200$ \\
\hline 3 & Unsatisfactory practice & 3 & $1201-1300$ \\
\hline 2 & Problematic practice & 2 & $1302-1400$ \\
\hline 1 & Unacceptable practice & 1 & $1401+$ \\
\hline 0 & No data set & 0 & No data \\
\hline
\end{tabular}

*Carbon dioxide concentrations cannot go below outside levels 
practice (Table 1). The indices were a culmination of the performance-based advice published about IEQ in over 70 sources. A QR score of 10/10 as an example of 'next practice', i.e. a level of performance that went beyond current best practice). A QR score of 1/10 was an example of 'unacceptable practice'. A QR score of 5/10 achieved the minimum required level of practice. (The EduTool:IEQ Evaluation Indices would need to be periodically updated to remain current.)

In the fourth stage, the results of the evaluation were succinctly communicated using the EduTool:IEQ Info-graphic - a data visualisation method. Built environment professionals are often more attracted to information that is communicated graphically, rather than textually or numerically. Therefore presenting technical information using data visualisation was believed to complement the natural tendencies of built environment professionals. In the theory on info-graphics, the shapes that are generated using numbers could have a greater impact on their audience compared with numbers alone (Sullivan, Case, Bolz, Mijksenaar, Ward, \& Burkhardt, 1996, p. 62). The EduTool:IEQ Info-graphic could succinctly communicate information about the IEQ performance inside a learning environment across the macro, mezzo

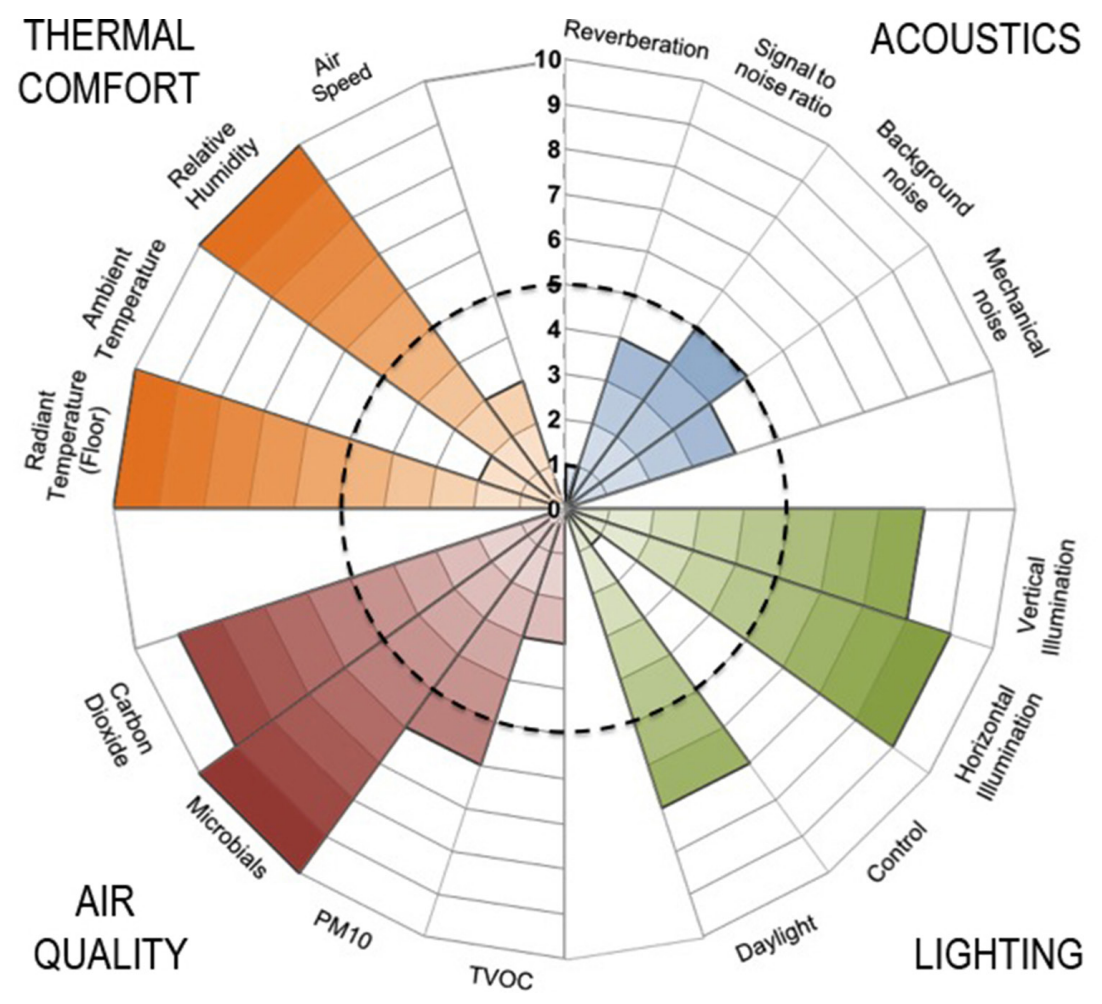

Figure 4. The EduTool:IEQ Info-graphic 
and micro scales. Each scale represented a unique level of analysis that targeted the specific information about the IEQ performance inside a learning environment that might be required by different built environment professionals. At the macro scale, the uniformity and total number of shaded cells in the EduTool:IEQ Infographic might be used to explain the overall IEQ performance inside the learning environment. At the mezzo level, the performance of the four IEQ sub-systems might be compared. At the micro level, it is possible to investigate the performance of individual IEQ components.

\section{IMPLICATIONS FOR TEACHERS AND DESIGNERS - USING EVIDENCE TO SHAPE DESIGN}

The EduTool:IEQ was developed to provide succinct and targeted information about the IEQ performance inside primary and middle school learning environments. The stakeholder groups that could benefit from receiving this information included learning environment operators (students, and educators), school administrators (facility managers and maintenance staff), and built environment professionals (school facility planners, architects, interior designers, industrial designers, engineers and builders).

Poor IEQ can reduce the effectiveness of good pedagogy as students occupying the space may struggle to see, to hear and understand instruction or to concentrate (Faustman, Silbernagel, Fenske, Burbacher, \& Ponce, 2000; Fisk, 2000; Heschong Mahone Group, 1999; Kats, 2006; Mendell et al., 2002; Mendell et al., 2005; Wakefield, 2002). As stated earlier learning environments with poor IEQ can exacerbate the effects of respiratory illness amongst susceptible children, causing them to be absent from school. Standardised test scores confirm students who are regularly absent from school achieve lower grades, compared with regular attendees (Balfanz \& Byrnes, 2012; Kohen, 2010; Moonie, Sterling, Figgs, \& Castro, 2008).

\section{CONCLUSION - IMPACT AND FUTURE DIRECTIONS}

Learning environments are the workplace of educators. A large body of research has been published about the relationship between employee productivity and the IEQ performance of workplaces (Fisk, 2011; Fisk \& Seppanen, 2007). While much of this research has focused on the productivity gains made by professionals working inside office buildings with good IEQ, this chapter argues that good IEQ would also assist the productivity gains of educators working inside learning environments. It would also reduce the costs associated with replacing, recruiting and training new teachers in schools, due to teacher turnover.

A 2010 report by the National Commission on Teaching and America's Future stated that "Green schools increase teacher retention" and teachers cite indoor air quality, access to daylight and views and better acoustics as reasons they prefer high-performing schools (Carroll, Fulton, \& Doerr, 2010). Lucas (as cited 
in Schneider, 2002) found that educator efficiency is lowered inside learning environments with excessive levels of noise. Poor acoustics inside the learning environment can also be a cause of stress and voice fatigue amongst educators (Frumkin, Geller, \& Nodvin, 2007).

For school administrators the benefits of the EduTool:IEQ are both inside and outside the learning environment. Owners and operators of school facilities are often in pursuit of new knowledge that will improve the quality of the facilities provided to students and educators (Newton, 2009). Inside the learning environment school administrators may be concerned with how IEQ issues are impacting on effective teaching and learning. Outside the learning environment, school administrators may be concerned with issues of efficiency, related to issues of school operation and management. There are examples in the literature that highlight how IEQ issues inside learning environments can result in higher operational costs due to increased demands placed on energy requirements (Apte et al., 2002; Catalina \& Iorcache, 2012; Dascalaki \& Sermpetzoglou, 2011). Through using the new POE tool, school administrators can access succinct and targeted information about the IEQ of their learning environments. Such detailed information could enable school administrators to budget for the required remedial works.

The greatest benefit to the built environment professionals is outside the learning environments, through the feedback loops provided by the new POE tool that can be used to inform their future practice (Baker, 2011). By streamlining the process surrounding the collection and analysis of objective data collected inside learning environments, the new POE tool aims to remove the perception amongst built environment professionals that conducting POEs is difficult (Preiser, 2002). The new POE tool communicates the results of an evaluation using an info-graphic a data visualisation method. Examples in the literature highlight the fact that built environment professionals are often more attracted to information that is communicated graphically rather than textually (Lawson, 2006). Built environment professionals can apply deductive reasoning to the succinct and targeted information provided by the new POE tool to identify the cause of specific of IEQ issues (Holyoak \& Morrison, 2005). The findings can empower built environment professionals to work with learning environment operators and school administrators, to devise a plan of action about the required remedial works (which may require physical or behavioural changes).

This chapter described the IEQ performance inside learning environments as a trigger for health and learning difficulties for students. Built environment professionals and school administrators can have a hand in improving the IEQ performance inside learning environments through making well-informed decisions based on the feedback loops provided by POE tools. The EduTool:IEQ is a new POE tool that communicates succinct information to multi-disciplinary audiences about the IEQ inside learning environments. The information is 'succinct' because it communicates the findings across three scales. To date the EduTool:IEQ has been 
used in ten evaluations. These evaluations have successfully drawn significant attention to the range of IEQ issues impacting on the health and wellbeing of school staff and students.

\section{REFERENCES}

Adeyeye, K., Piroozfar, P., Rosenkind, M., Winstanley, G., \& Pegg, I. (2013). The impact of design decisions on post occupancy processes in school buildings. Facilities, 31(5/6), 255-278.

AFA. (2009). Annual report 2009. Retrieved September, 2012, from www.asthmaaustralia.org.au

AIHW. (2011). Australia's welfare 2011 (Australia's welfare series no. 10). Canberra: Author.

Ali, H., Almomani, H., \& Hindeih, M. (2009). Evaluating indoor environmental quality of public school buildings in Jordan. Indoor and Built Environment, 18, 66-76.

Apte, M. G., Hodgson, A. T., Shendell, D. G., Dibartolomeo, D., Hochi, T., Kumar, S., Lee, S. M., Liff, S. M., Rainer, L. I., Schmidt, R. C., Sullivan, D. P., Diamond, R. C., \& Fisk, W. J. (2002). Energy and indoor environmental quality in relocatable classrooms. Berkeley, CA: Lawrence Berkeley National Laboratory

ASHRAE. (2010). Research strategic plan 2010-2015: Navigation for a sustainable future. Retrieved November 9, 2013, from www.ashrae.org

Baker, L. (2011). What school buildings can teach us: Post-occupancy evaluation (Unpublished masters thesis). Deptartment of Architecture, University of California, Berkeley, CA.

Balfanz, R., \& Byrnes, V. (2012). Chronic absenteeism: Summarizing what we know from nationally available data. Baltimore, MD: Johns Hopkins University Center for Social Organization of Schools.

Belanger, E., Kielb, C., \& Lin, S. (2006). Asthma hospitalization rates among children, and school building conditions by New York State school districts 1991-2001. Journal of School Health, 76(8), 408-413.

Bluyssen, P. M. (2013, May 22). Understanding the indoor environment [Inaugral speech]. Faculty of Architecture, Delft University of Technology, The Netherlands.

Bluyssen, P. M., \& Loomans, M. G. L. C. (2003). A framework for performance criteria of healthy and energy-efficient buildings. Proceedings of Healthy Buildings, Singapore, 446-452.

Cândido, C., de Dear, R., \& Lamberts, R. (2011). Combined thermal acceptability and air movement assessments in a hot humid climate. Building and Environment, 46, 379-385.

Cândido, C., de Dear, R., Thomas, L., Kim, J., \& Parkinson, T. (2013). Introducing BOSSA: The building occupants survey system australia. Ecolibrium, 42-46.

Carroll, T. G., Fulton, K., \& Doerr, H., (2010). Team up for 21st century teaching and learning: What research and practice reveal about professional learning [Condensed Excerpts]. Arlington, VA: National Commission On Teaching And America's Future.

Castree, N. (2005). Nature (p. 214). London: Routledge.

Catalina T., \& Iordache, V. (2012). IEQ assessment on schools in the design stage. Building and Environment, 49, 129-140.

Center for Disease Control and Prevention. (2006). Asthma prevalence, health care use and mortality: United States, 2003-2005. Atlanta, GA: National Centre for Health Statistics. Retrieved from http:// www.cdc.gov/nchs/products/pubs/pubd/hestats/ashtma03-05/asthma03-05.htm

Coalition for Healthier Schools. (2013). Towards healthy schools 2015. Retrieved December 11, 2013, from www.healthyschools.org

Creswell, J., \& Plano Clark, V. (2011). Designing and conducting mixed methods research (2nd ed.). London: Sage.

Daisy, J., Angell, W., \& Apte, M. (2003). Indoor air quality, ventilation and health symptoms in schools: An analysis of existing information. Indoor Air, 13, 53-64.

Dascalaki, E., \& Sermpetzoglou, V. (2011). Energy performance and indoor environmental quality in Hellenic schools. Energy and Buildings, 43, 718-727.

Earthman, G.I. (2004). Prioritization of 31 criteria for school building adequacy. Baltimore, MD: American Civil Liberties Union Foundation of Maryland. 
Environment and Human Health Inc. (2010). LEED certification, where energy efficiency collides with human health: An EHHI report. North Haven, CT: Author. Retrieved from http://www.ehhi.org/ leed

Faustman, E. M., Silbernagel, S. M., Fenske, R. A., Burbacher, T. M., \& Ponce, R. A. (2000). Mechanisms underlying children's susceptibility to environmental toxicants. Environ Health Perspec, 108 (Suppl. 1), 13-21.

Fisk, W. (2000). Estimates of potential nationwide productivity and health benefits from better indoor environments: An update. In J. D. Spengler, J. M. Samet, \& J. F. McCarthy (Eds.), Indoor air quality handbook (Vol. 4). New York, NY: McGraw-Hill.

Fisk, W. (2011). Benefits and costs of improved IEQ in U.S. offices. Indoor Air, 21(5), 357-367.

Fisk, W., \& Seppanen, O. (2007, June 10-14). Providing better indoor environmental quality brings economic benefits. Proceedings of Clima 2007: Well-being indoors. FINVAC, Helsinki, Finland.

Froeyman, A. (2012). The ontology of causal process theories. Philosophia, 40(3), 523-538. doi:10.1007/ s11406-011-9329-2

Frumkin, H., Geller, R., \& Nodvin, J. (2007). Safe and healthy school environments. Oxford: Oxford University Press.

Green Building Council Australia. (2013). Green star education Version 1. Retrieved January 11, 2013, from http://www.gbca.org.au

Grant, R., \& Brito A. (2010). Chronic illness and school performance: A literature review focusing on asthma and mental health conditions. Retrieved March 5, 2011, from http://www.childrenshealth fund.org/sites/default/files/chronic-illness-and-school-performance.pdf

Greener, I. (2011). Designing social research: A guide for the bewildered. London: Sage.

HEFCE. (2006). Guide to post occupancy evaluation. Bristol, UK: Higher Education Funding Council for England.

Heschong Mahone Group. (1999). Daylighting in schools: An investigation into the relationship between daylighting and human performance. Fair Oaks, CA: Pacific Gas and Electric Company.

Higgins, S., Hall, E., Wall, K., Woolner, P., \& McCaughey, C. (2005). The impact of school environments: A literature review. London: Design Council. Retrieved July 1, 2009, from www.design-council.org.uk/

Holyoak, K. J., \& Morrison, R. G. (2005). Thinking and reasoning: A reader's guide. In K. J. Holyoak \& R. G. Morrison (Eds.), The Cambridge handbook of thinking and reasoning (pp. 1-9). Cambridge, UK: Cambridge University Press.

IOM. (2011). Climate change, the indoor environment and health. Washington, DC: National Academies Press.

IPMVP. (2002). International performance measurement and verification protocol Volume II: Concepts and practices for improved indoor environment quality. Washington, DC: IPMVP Inc. Retrieved March 10, 2011, from http://smartenergy.illinois.edu/pdf/archive/ipmvpvol2.pdf

Joas, H. (1996). The creativity of action. Chicago, IL: University of Chicago Press.

Johnson, P., \& Kritsonis, W. (2010). Greener schools, greater learning, and the LEED value. Doctoral Forum. National Journal for Publishing and Mentoring Doctorial Student Research, 7(1).

Kats, G. (2006). Greening America's schools-Costs and benefits. A capital E report. Retrieved October 1, 2009, from www.cape.com/ewebeditpro/items/O59F9819.pdf

Kim, J., \& De Dear, R. (2012). Identifying substantive IEQ factors for efficient building management. The 46th Annual Conference of the Architectural Science Association, ANZAScA, Gold Coast, Australia.

Kim, S., Paulos, P., \& Mankoff, J. (2013, April 27). inAir: A longitudinal study of indoor air quality measurements and visualizations (pp. 2745-2754). CHI 2013: Changing Perspectives. Paris, France.

Kohen, D. (2010). Asthma and school functioning. Health Report, 21, 35-45

Lawson, B. (2006). How designers think: The design process demystified. London: Architectural Press.

Loftness, V., Lam, K., \& Hartkopf, V. (2007). Education and environmental performance-based design: A Carnegie Mellon perspective. Building Research \& Information, 33(2), 196-203.

Luther, M. (2012, July 8-12). Review of measurements in schools to improve IEQ. Paper presented at 10th International Conference of Healthy Buildings, Queensland University of Technology, Brisbane, Queensland.

Luther, M. B., \& Schwede, D. A. (2006). Mobile Architecture and Built Environment Laboratory (MABEL) - A building performance evaluation tool. BDP Environment Design Guide, 69, 1-7. 
Mendell, M., \& Heath, G. (2005). Do indoor pollutants and thermal conditions in schools influence student performance? A critical review of the literature. Indoor Air, 15, 27-52.

Mendell, M., Fisk, W., Dreiss, K., Levin, H., Alexander, D., Cain, W., Gimam, J. R., Hines, C. J., Jensen, P. A., Milton, D. K., Rexroat, L. P., \& Wallingford, K. M. (2002). Improving the health of workers in indoor environments: Priority research needs for a national occupational research agenda. American Journal of Public Health, 92, 1430-1440.

Meng, Y. Y., Babey, S. H., \& Wolstein, J. (2012). Asthma-related school absenteeism and school concentration of low-income students in California. Prevention \& Chronic Disease, 9. Retrieved October 23, 2013, from http://www.cdc.gov/pcd/issues/2012/11_0312.htm

Merker, B. (2010). Nested ontology and causal options: A paradigm for consciousness. Retrieved October 3, 2013, from cogprints.org/6853/

Moonie, S. Sterling, D., Figgs, L., \& Castro M. (2008). The relationship between school absence, academic performance, and asthma status. The Journal of School Health, 78(3), 140-148.

Newton, C. (2009). Learning through prefabrication. Undisciplined! Design Research Society Conference 2008 Sheffield Hallam University, Sheffield, UK, 16-19 July 2008.

OECD. (2012). Equity and quality in education: Supporting disadvantaged students and schools. Retrieved June 5, 2013, from www.oecd.org/education/school/50293148.pdf

OECD. (2013). Effectiveness, efficiency and sufficiency: An OECD framework for a physical learning environments module (Draft). Retrieved January 7, 2014, from http://www.ibrarian.net/navon/ mismachKarov.jsp?ppid $=18741918$

Plotkin, H. (2008). The central problem of cognitive science: The rationalist-empiricist divide. Journal of Mind and Behavior, 29(1-2), 1-16.

Preiser, W. (2001). Feedback, feed forward and control: Post occupancy evaluation to the rescue. Building Research and Information, 29(6), 456-459.

Preiser, W. F. E. (2002). The evolution of post-occupancy evaluation: Toward building performance and universal design evaluation. In W. F. E. Preiser (Ed.), Learning from out buildings: A state-of-thepractice summary of post-occupancy evaluation. Washington, DC: National Academy Press.

Rodgers, R. F. (1990). Recent theories and research underlying student development. In N. J. Evans, D. S. Forney, \& F. Guido-DiBrito (Eds.), Student development in college: Theory, research, and practice. San Francisco, CA: Jossey Bass.

Rutter, M. (1979). 15,000 hours: Secondary schools and their effect on children. London: Harvard English Press.

Sanoff, H. (2001). School building assessment methods. Washington, DC: National Clearinghouse for Educational Facilities.

Schneider, M. (2002). Do school facilities affect academic outcomes? Washington, DC: National Clearinghouse for Educational Facilities.

Simons, E., Hwang, S., Fitzgerald, E., Kielb, C. M. S., \& Lin, S. (2010). The impact of school building conditions on student absenteeism in upstate New York. American Journal of Public Health, 100(9), $1679-1686$.

Sherwin, R. P. (1983). What is an adverse health effect? Environmental Health Perspectives, 52, 177-182.

Soccio, P. (2014). Communicating succinct and targeted information to a multidisciplinary audience about the indoor environment quality inside Australian primary and middle school classrooms (Unpublished PhD). The University of Melbourne, Melbourne.

Sullivan, P., Case, D., Bolz, N., Mijksenaar, P., Ward, S., \& Burkhardt F. W. (1996). Information design and infographics. Netherlands: European Institute for Research and Development of Graphic Communication.

USEPA. (2008). Mold remediation in schools and commercial buildings. Retrieved April 9, 2012, from http://www.epa.gov/mold/moldguide.html

Vischer, J. (2002). Post-occupancy evaluation: A multifaceted tool for building improvement. In W. F. E. Preiser (Ed.), Learning from out buildings: A state-of-the-practice summary of post-occupancy evaluation (pp. 23-34). Washington, DC: National Academy Press.

Vittori, G. (2002). Green and healthy buildings for the healthcare industry white paper. In CleanMed. Austin, TX: Center for Maximum Potential Building Systems. 
Wakefield, J. (2002). Learning the hard way: The poor environment of America's schools. Environmental Health Perspectives, 110(6), 298-305.

White, S. K. (2004). The very idea of a critical social science. In F. Rush (Ed.), The Cambridge companion to critical theory. Cambridge: Cambridge University Press.

World Health Organization. (2006). Principles for evaluating health risks in children associated with exposure to chemicals. Environmental Health Criteria, 237.

\section{Philippa Soccio}

Melbourne School of Design

Faculty of Architecture, Building and Planning

The University of Melbourne 